\title{
Lisa I. IMPROVEMENT OF THE CONSTRUCTION INDUSTRY MANAGEMENT OF LATVIA BASED ON THE EXPERIENCE OF CONSTRUCTION ECO-LABELLING IN SCANDINAVIA
}

Об’єктом дослідження є будівельна галузь Латвї. Дана галузь народного господарства Латвї в останні роки переживає значні падіння $і$ злети. Вивчення причин та наслідків даних коливань є важливим для економіки країни. 3 істотних недоліків можна назвати високий рівень тінвової економіки в будівництві, використання неякісних будівельних матеріалів, брак робочої сили на всіх рівнях галузі, довгий бюрократичний шлях при оформленні документів та ін.

Удосконалення будівельної галузі Латвї можливо із залученням закордонного досвіду. На прикладі країн Скандинавї розглянуто один з важливих етапів становлення якісного та екологічного будівництва. У Північних країнах, починаючи з 1989 року застосовують до зданих в експлуатацію будівель систему екомаркування будівель. Дані документи підтверджують використання якісних будівельних матеріалів, енергоефективність будівлі, сертифікацію компанї і використаних матеріалів. Документи по екомаркуванню необхідні для житлових будівель, приватних будинків і всіх типів навчальних закладів $і$ дитячих садків. Це означає, що для будівництва застосовуються тільки матеріали, які пройшли суворий відбір за якістю і хімічним складом.

Використовуючи досвід роботи зі скандинавськими клієнтами, автором було досліджено досвід впровадження системи екомаркування будівель, а також зібрана необхідна інформація для вивчення теми дослідження та визначення підходів введення досвіду Північних країн в будівельну галузь Латвї. Введення екомаркування будівель і паспортів на приватні будинки, багатоповерхові житлові будинки, школи, дитячі садки та інші навчальні заклади приведуть до використання більш якісних будівельних матеріалів. А також до розуміння відповідальності і у генеральних підрядників будівництва, $і$ у будівельних компаній, $i$ у постачальників будівельних матеріалів. Також використання екологічних будівельних матеріалів в житлових і навчальних закладах приведуть до поліпшення здоров'я населення, зокрема до зменшення алергї $i$ захворювань дихальної системи.

Впровадження екомаркування та паспортів на будівлі необхідно вводити на державному рівні, а також потрібно адаптувати для Латвї вимоги Свропейського Союзу щодо використання екологічних матеріалів в будівництві. Важливо грамотно і систематично розробити модель впровадження сучасних підходів управління будівельною галуззю на основі досвіду передових країн. Жорсткість вимог до всіх етапів будівельного процесу, використання безпечних для здоров'я будівельних матеріалів, а також посилення вимог до охорони праці підвищить якісний рівень всієї будівельної галузі в цілому. Введення системи екомаркування будівель займе певний час, але призведе до позитивних результатів.

ключові слова: будівельна галузь, екомаркування будівель, впровадження досвіду, будівельні матеріали, Basta, Sroan.

\section{Introduction}

The construction industry is of great importance for development of the national economy of the state. Thanks to the development of construction, the economic efficiency of many other branches of the economy is increasing. The components of the construction industry are the production of construction materials, construction and finishing, the sale of construction materials, road construction and architectural and design work. For the successful operation of the industry as a whole, it is important to balance and balance all groups of the construction market. In recent years, the European Union has made a significant emphasis on safe and quality construction, the use of environmental materials, compliance with European standards, the protection of workers and the use of the latest solutions in architecture. Also increasingly popular in Europe and the world's leading countries are issued documents for constructions, which indicate energy efficiency and ecolabeling of constructions. It is important to develop and improve the construction industry in all regions of the country, using the experience and innovations of the leading countries of the EU and the world. At the moment, there are serious problems in the construction industry in Latvia, which require immediate solutions both at the state level and in the organizations involved in the construction. It should be noted:

- high level of shadow economy;

- long terms of project approvals;

- lack of labor from simple workers to managers of construction processes;

- use of cheap and poor-quality construction materials; 
- short guarantee periods after commissioning of constructions, ineffective development of financing from the funds of the European Union, etc.

Therefore, it is relevant to study the dynamics of the development of the construction industry in the country, timely assessment of risks and results of innovations in the tax sphere, the system of public procurement, as well as in the system for issuing permits for the construction and use of environmental construction materials. To stabilize the construction industry, a well-planned state program and the use of the experience of leading European countries are necessary

\section{The object of research and its technological audit}

The object of research is the construction industry in Latvia, which should be balanced with the overall economic development of the country. The volume of construction and the structure of the market are directly related to overall economic development. Over the past 10 years of development, Latvia's construction industry has shown both significant growth and a rapid decline. Table 1 shows the volume of construction products and the total amount of construction work in the construction industry in the period from 2008 to 2017. Starting with a stable high state in 2008, further to a serious decline in 2010. Further to stagnation or weak growth from 2011 to 2016 and finally to growth in 2017. Significant fluctuations in the development of the construction industry affect the entire economic situation in the country as a whole.

Table 1

The total volume of construction works in thousands of euros, sales of building materials in thousands of euros in the construction industry from 2008 to 2017

\begin{tabular}{|c|c|c|}
\hline Year & $\begin{array}{c}\text { Construction production } \\
\text { (thousand EUR) }\end{array}$ & $\begin{array}{c}\text { Total amount of construction } \\
\text { works (thousand EUR) }\end{array}$ \\
\hline 2008 & 2516313 & 2424734 \\
\hline 2009 & 1449794 & 1311311 \\
\hline 2010 & 1077886 & 1048210 \\
\hline 2011 & 1235994 & 1211338 \\
\hline 2012 & 1515188 & 1486194 \\
\hline 2013 & 1661001 & 1631083 \\
\hline 2014 & 1796874 & 1765846 \\
\hline 2015 & 1743726 & 1743725 \\
\hline 2016 & 1420340 & 1455432 \\
\hline 2017 & 1736568 & 1761072 \\
\hline
\end{tabular}

Note: compiled by the author according to [1]

The development of Latvian construction should be based on the ability to compete in the domestic and foreign markets, the high quality of professional services and competitiveness in attracting capital. The construction sector needs to change, increase its productivity, innovation, export potential and emphasize the achievements of the industry.

One of the most problematic places in the construction industry in Latvia is the fragmentation and inconsistency of all participants. In connection with this, the level of the shadow economy in construction is high, a long bu- reaucratic process of coordinating all documents, the slow development of financing from the Eurofunds, the lack of a qualified labor force due to a massive outflow of specialists to developed labor markets, etc.

\section{The aim and objectives of research}

The aim of this research is analysis of the possibility of using the eco-labeling experience of buildings in the Scandinavian countries to optimize the activities of the construction industry in Latvia.

To achieve the aim it is necessary to solve the following tasks:

1. To study the current state and trends of the Latvian construction market.

2. To assess the possibility of eco-labeling of buildings in the building industry of Latvia based on the experience of Scandinavia.

3. To formulate the prospects and necessary conditions for the introduction of eco-labeling in the construction industry in Latvia.

\section{Research of existing solutions of the problem}

The analysis of problems and proposals for solutions in the construction industry of Latvia is being carried out by a number of organizations:

- Ministry of Economy;

- Ministry of Environmental Protection and Regional

Development;

- Latvian partnership of construction contractors;

- Association of Latvian builders;

- Association of merchants of building materials;

- Center for Sustainable Business Development SSE Riga;

- Council of foreign investors in Latvia and many others.

Recent studies by the Stockholm School of Economics in Riga (SSE Riga) show a still high level of shadow economy in Latvia in 2017 - $35.2 \%$. The main share is occupied by salaries in envelopes, bribes and unofficial construction work [2]. Scientists-specialists apply the method of statistical analysis and the method of sociological surveys in annual studies.

The Latvian partnership of construction contractors has achieved the introduction of individual maps of the executors of construction works, beginning with the foreman, ending with the simple assistants of the builders [3]. This organization also introduces joint liability agreements in which all participants in the construction process are responsible both for the quality of work and for paying taxes [4].

The Ministry of Finance of Latvia, the State Revenue Service and the Latvian partnership of construction contractors signed a memorandum of cooperation on 13.07.2018 with a view to long-term development of the Latvian construction industry, reducing the shadow economy and developing fair competition in construction [5].

The Council of Foreign Investors in Latvia points to long bureaucratic steps in agreeing projects and distrust of foreign investors [6].

The Association of Latvian Builders notified of the introduction of electronic timekeeping from 01.10.2017. At construction sites, all builders are monitored by elec- 
tronic maps. These measures serve to reduce the shadow economy - take into account the working day, overtime hours, the number of people employed at construction sites, etc. [7].

Working together of all interested organizations will undoubtedly lead to an improvement in the situation in the construction industry in Latvia.

Study of the dynamics and forecast construction industry from 2009 to 2020 reflected in the international statistical agencies Statista [8], but do not take into account evidence that hinder the development of growth, such as the shadow economy and labor shortages.

The commissions of the European Union analyze the current developments in the construction industry in Latvia and point to positive aspects and problems [9]. However, the described parameters are not fully considered, due to insufficient information.

The Council of Ministers of the Nordic countries, which was founded in 1971, unites the intergovernmental work of the Scandinavian countries, as well as Iceland, Greenland, the Faroe Islands and the Aland Islands. The Council regularly conducts research on environmental protection in the region, energy efficiency, living standards and the development potential of the entire Northern region as a whole. In 2007, a large-scale study of the construction industries of all Scandinavian countries, as well as the Baltic countries, was conducted [10]. During this period, Latvia experienced a high growth in construction both in the residential sector, as well as in trade and storage facilities, road construction, engineering facilities and others. Banks willingly financed projects, demand for construction projects exceeded offers. The authors of the study [10] pointed out the need for more precise control over the plans and deadlines for the execution of construction projects, the financial sector was recommended to analyze the financing of projects more thoroughly, and also offered to make a public database of building materials. However, the recommendations were not heard in Latvia, and in 2009 the construction industry plunged into a severe crisis. Turnovers collapsed, the banking sector sharply reduced funding, new projects were frozen, thousands of people were left without work.

Canadian manufacturers and exporters (CME) are $\mathrm{Ca}^{-}$ nada's largest trade and industry association, as well as the voice of manufacturing and global business in Canada. The Association represents more than 10000 leading companies throughout the country. More than 85 percent of CME members are small and medium-sized enterprises. The new Enterprise Canada platform since 2014 directly links Canadian companies to international business and technological opportunities. For this, international research is conducted in various branches of the national economy. This association has analyzed the possibilities of the Latvian construction market, as well as the possibility of exporting construction products from Canada to Latvia [11]. It is shown that Latvia and Canada are climatically similar, and in both countries the construction of wooden houses is developed. However, the export of construction products from Canada to Latvia is problematic due to the long distance and high cost of goods.

In work [12] it is said that increasing the competitiveness of construction enterprises is one of the most important strategic goals of the construction industry. The loss of the company's competitiveness is the biggest threat. The main focus of this work is improvement of the quality and safety of construction companies - research was conducted to obtain more detailed information on the quality indicators used by building materials producers in Latvia. At the end of this work, the authors will briefly outline the results of the study. However, manufacturers of building materials in Latvia do not always pay attention to the quality of the goods, even if this product is certified. To lower the price of the cost of goods, manufacturers often reduce the quality. As a result, the quality of the entire construction site suffers, as well as safety at construction enterprises.

The authors of [13] describe the eco-labeling of the European Union, an ecological label developed by the European Commission to promote environmental excellence in products and services. The paper discusses the relationship between the European Union eco-label and national ecolabeling schemes, and then focuses on building materials covered by the European Union's eco-labeling criteria. Scientists are exploring the possibilities of improving the quality of construction processes, as well as systematizing the data of the European Union on the requirements of the countries of participants to the issue of eco-labeling. But the question remains when Latvia will be ready to introduce its national eco-labeling and will pay due attention to the issues of quality and health of future generations.

\section{Methods of research}

To achieve the research aim, the following methods are used:

1. Method of sociological surveys. To study the ecolabeling system, the author conducted surveys of construction materials suppliers in Scandinavia, as well as surveys of construction companies that build construction projects in Scandinavia.

2. The method of expert assessments. Personal meetings were held with representatives of international companies at a construction exhibition in Stockholm in April 2018.

3. The statistical method. Information was analyzed on the dynamics of the development of the construction industry in Latvia from 2010 to 2017.

\section{Research results}

The construction industry, which contributes more than a billion EUR to the economy of Latvia and employs almost 60,000 people, is one of the most important sectors of the national economy. Not only because it is a branch of the national economy of Latvia, in which local entrepreneurs successfully compete with foreign firms, but also because it has a huge development potential.

The volume of construction products in 2017, compared with the same period in 2016 , increased by $19.5 \%$ (Table 2) [14]. The volume of construction products in actual prices was 1736 million EUR. The increase in the volume of construction was affected by an increase in the volume of construction of engineering structures by $30.6 \%$. The increase in the volume of construction work was practically in all areas of engineering construction:

- in the construction of roads, streets, airfield runways and railways - by $28.2 \%$;

- in the construction of ports, waterways, dams and other hydraulic structures - by $51.4 \%$. 
A significant increase was also observed in the construction of trunk pipelines, trunk lines and transmission lines - by $49.5 \%$, in the construction of local pipelines and cables - by $41.0 \%$ and on the construction of other engineering facilities - by $81.7 \%$.

During the construction of buildings, the volume of production increased by $11.8 \%$, which was affected by the growth in volume in the non-residential construction sector by $20.2 \%$. In the construction of residential buildings, the fall was $11.0 \%$.

In $2017,2.540$ permits were issued for the construction, reconstruction and renovation of residential buildings with a total area of $531.1 \mathrm{~m}^{2}$, including new construction, 1.948 construction permits with a total area of $395.8 \mathrm{~m}^{2} .202$ permits were issued for the construction of industrial buildings and warehouses with a total area of 336 thousand $\mathrm{m}^{2}$. Of these, 113 permits were issued for the construction of new industrial and storage facilities with a total area of 134.7 thousand $\mathrm{m}^{2}$.

Table 2

The volume of construction products in Latvia and changes in 2017

\begin{tabular}{|c|c|c|}
\hline $\begin{array}{l}\text { Distribution of construction proj- } \\
\text { ects by designation }\end{array}$ & $\begin{array}{c}\text { Total in } 2017 \text { (in } \\
\text { current prices, } \\
\text { million EUR) }\end{array}$ & $\begin{array}{l}\text { In } 2017, \\
\text { compared with } \\
\text { 2016, \% }\end{array}$ \\
\hline Residential buildings & 216.1 & -11 \\
\hline Non-residential buildings & 754.4 & 20.2 \\
\hline Hotels and similar buildings & 41.3 & -32.8 \\
\hline Office buildings & 128 & 28.7 \\
\hline Wholesale and retail premises & 62.2 & 77.7 \\
\hline Industrial and warehouse premises & 139.9 & 33.3 \\
\hline $\begin{array}{l}\text { Schools, universities and research } \\
\text { centers }\end{array}$ & 91.8 & 43.4 \\
\hline Medical institutions & 24.4 & -37.1 \\
\hline Engineering constructions & 765.5 & 30.6 \\
\hline $\begin{array}{l}\text { Roads, railways and runways } \\
\text { at airports }\end{array}$ & 342 & 28.2 \\
\hline Bridges and tunnels & 19 & -14.3 \\
\hline Ports and dams & 61.5 & 51.4 \\
\hline $\begin{array}{l}\text { Trunk pipelines, communication } \\
\text { and power transmission lines }\end{array}$ & 141.4 & 49.5 \\
\hline Local pipelines & 148.8 & 41 \\
\hline Total & 1736 & 19.5 \\
\hline
\end{tabular}

Note: compiled by the author according to [14]

Along with indicators of growth of the construction industry in Latvia, it is necessary to point out the problems. One of the significant problems is the high level of the shadow economy, both in construction and in the state as a whole (Table 3). 16.05.2018, the next annual report of the Stockholm School of Economics in Latvia was published, which says that despite the overall economic growth in Latvia in 2017, the level of the shadow economy has also increased. In Latvia, the shadow economy index (\% of GDP) is $22 \%$, in neighboring Lithuania and Estonia $18.2 \%$.
The index of the shadow economy level in the Baltic States (\% of GDP) in 2009-2017

\begin{tabular}{|c|c|c|c|}
\hline Year & Latvia & Lithuania & Estonia \\
\hline $2017-2016$ & +1.3 & +1.7 & +2.8 \\
\hline 2017 & 22.0 & 18.2 & 18.2 \\
\hline 2016 & 20.7 & 16.5 & 15.4 \\
\hline 2015 & 21.3 & 15.0 & 14.9 \\
\hline 2014 & 23.5 & 12.5 & 13.2 \\
\hline 2013 & 23.8 & 15.3 & 15.7 \\
\hline 2012 & 21.1 & 18.2 & 19.2 \\
\hline 2011 & 30.2 & 17.1 & 18.9 \\
\hline 2010 & 38.1 & 18.8 & 19.4 \\
\hline 2009 & 36.6 & 17.7 & 20.2 \\
\hline
\end{tabular}

Note: compiled by the author according to [2]

The highest level of shadow economy was in the construction industry of Latvia, reaching $35.2 \%$. This indicator in 2017 was lower, since in 2016 the level of shadow economy in construction was $38.5 \%$. The state and various associations and associations try to solve this problem by:

- input of electronic time records in construction;

- classification of occupations in construction;

- introduction of a joint liability agreement;

- fixing the minimum wages of builders by classification groups;

- regulation of the process of public procurement for facilities.

Every year, the problem of the lack of labor in the construction industry becomes more important. There is a shortage of both qualified personnel and support staff. In due time the building technical schools and schools were closed or reorganized, therefore there is no place to take specialists. Also on engineering professions are going to study for today not with great desire. The emigration of the population and skilled personnel greatly influences. Abroad, workers in the construction industry receive several times more payment for their work. In Latvia in 2017, permits for various facilities have been signed, but the process of putting it into operation is often hampered precisely because of a shortage of labor. The way out of this situation is labor attraction from the near abroad. To date, one of the mandatory conditions for the managers of construction projects, superintendents and responsible persons is the knowledge of the Russian language, since residents of Ukraine, Kazakhstan, Uzbekistan, Moldova and other countries work on the construction sites of Latvia. Residents of these countries do a good job, but they do not speak and understand Latvian. For the construction process to be effective, it is necessary to understand the goals, progress and results of any construction.

It is necessary to point out another problem in the construction industry in Latvia - the use of the cheapest building materials in most cases. The guarantee for the construction of the facility in Latvia is 2 years, during this period of time serious violations due to low-quality materials are almost not formed. But after the expiration 
of this time, problems with external works and finishing work come to the surface. But there is no one to answer for the cracks, drips, breaks. All problems should be solved already by the owner of buildings or premises. The reason for the violation of human health is the use of building materials with inadequate standards for the chemical composition of products. Especially it concerns residential premises, schools, kindergartens and other educational institutions. In the building materials are added various plasticizers, chemical additives, which make products cheaper and increase the impact on people's health. How to understand the customer, what materials are better and safer for health? The answer is the experience of Scandinavian countries in the eco-labeling of residential buildings and educational institutions.

In the Scandinavian countries there are 2 main eco-labeling systems - BASTA and SWAN. The requirements apply to Sweden, Norway, Denmark, Finland and Iceland. Criteria of requirements underlie the classification of standards 1272/2008 from the European Chemicals Agency (ECHA) [15].

Environmental labeling Nordic Ecolabeling provides requirements for the use of energy, chemical products, construction products, goods, buildings and a number of internal environmental factors that are relevant to health and the environment. This eco-labeling also provides requirements for quality management in the construction process, as well as the transfer of the building to residents and administration.

Eco-labeled buildings are evaluated based on the life cycle perspective and:

- have low energy consumption;

- meet high requirements for environmental protection and health on construction products, materials and chemical products;

- provide a good internal environment and low carbon dioxide emissions;

- have a guaranteed quality construction process.

In general, eco-labeling of buildings should have residential single-family houses, multi-storey houses with apartments, school educational institutions and kindergartens, institutions for the care of elderly people and others. Special requirements apply to the entire building frame of the building. The foundation must be insulated from heat loss, moisture penetration and, if necessary, also protected from penetration of radon. Thus, eco-labeling establishes requirements for materials and chemicals for insulation of the foundation and socle, as well as all materials that are below the base plate or above it.

Inspections verify compliance with eco-labeling requirements. Typically, the original copies of the submitted certificates, test reports, purchase statistics and various data used for calculations are checked. To obtain the markings, a general description of the building is prepared with a complete description:

- detailed information on the number of floors, the number of square meters of living space and information about subsidiary premises;

- measurement of electricity consumption for each living quarters. Preschool and school buildings should include measurement of electricity consumption for operation;

- type of housing or supporting structure of the building, facade, roof, foundation, heating system and ventilation system;
- detailed information on any additional premises (garage, warehouse, room for bicycles, room for storage of waste, etc.);

- the number of classes in schools and kindergartens, departments, etc.

The license holder must be responsible for all requirements in the criteria document and for meeting the requirements, regardless of what work is being done, until the building is ready for operation. For example, if there are subcontractors at the site, the license owner is responsible for the fact that the subcontractor is informed of the requirements and is responsible for their implementation.

The requirements for the eco-labeling criteria BASTA [16] and SWAN [17] should correspond to:

- energy efficiency of buildings;

- quality/level of illumination;

- energy consumption of household appliances;

- sorting of garbage;

- protection against penetration of radon gas into the house;

- control of humidity in rooms, ventilation, daylight, formaldehyde emission and others.

All suppliers of building materials are obliged to fill out special declarations for each type of product, where the components of the product are painted in detail. Responsibility for the reliability of this information is borne by the manufacturer of building materials. If a product does not meet the criteria, then it can't be used for the construction of the facility. Companies that supply facade materials or roofing materials usually immediately certify their system, which includes declarations from manufacturers of building materials.

Thus, the Scandinavian countries show the experience of protecting the environment, protecting public health and stable quality construction.

\section{SWOT analysis of research results}

Strenghts. This study shows that the construction industry in 2017 has a positive trend, an increase of $19.5 \%$ in 2017. The role of foreign investment in the construction industry is increasing - construction of IKEA and Akropolis shopping centers is under way, numerous office and warehouse centers are being built with foreign investments. In 2017-2018, standards for the electronic recording of the working time of builders are signed, a minimum wage is established, and a joint responsibility agreement is signed. The industry is actively reacting to the experience of European and Scandinavian companies, export of construction industry.

Weaknesses. A high level of shadow economy, a shortage of labor, low rates of Eurofinancing, the outflow of qualified specialists abroad, a lack of educational institutions that prepare skilled labor, bureaucracy from the beginning to the end of the project are indicated.

Opportunities. Studying the experience of Scandinavian countries and introducing it into the construction industry in Latvia will invariably lead to positive trends. Reducing the level of the shadow economy will affect the transparency of transactions in construction, increase in wages, but also increase the cost of construction. This study can also be useful for Lithuania and Estonia, since there are similar problems with emigration of labor and economic indicators. 
Threats. The increased pace of construction leads to a shortage of labor, which in turn leads to the importation of labor from abroad. Also, inevitably leads to an increase in wages and construction costs. A strong overheating in construction, when the number of projects being built is faced with a shortage of labor and substantial increases in expenditures, can lead to a new crisis similar to the 2008-2009 crisis.

\section{Conclusions}

1. In the course of this research, a statistical analysis of the situation in the construction industry in Latvia at the end of 2017 is carried out. According to the results, the total growth in 2017 compared to the previous year $19.5 \%$ or 1.736 million EUR. Negative dynamics is shown by the construction of residential premises, hotels and medical centers. All other groups of construction projects show stable growth. The shadow economy of Latvia and neighboring Lithuania and Estonia is considered - despite the efforts of the Government of Latvia, the Ministry of Finance, the Ministry of Economy of the Financial Inspection, the level of the shadow economy continues to grow. In 2017, the shadow economy index of Latvia showed $22 \%$, and in the construction sector $35.2 \%$. As a result of the research, the strengths of the construction industry in Latvia have been determined:

- the number of foreign investments in construction projects is growing;

- many trading, warehousing, office and residential projects are opened or are being prepared for opening, such as Ikea, Akropolis, Jauna Teika and others;

- Latvian construction companies successfully compete

in European markets. Among the strongest players in the market are: UPB AS, Skonto Buve SIA, RE \& RE SIA, Oberon Tehnika SIA;

- turnover of building supermarkets is also growing. Among the strongest players can be called DIY DEPO with a turnover of 219.105 million EUR, DIY Kurshi 72.198 million EUR, DIY Kruza - 14.566 million EUR. Weaknesses of the construction industry in Latvia:

- high level of shadow economy - $35.2 \%$;

- lengthy bureaucratic delays with the execution of documents;

- untimely development of financing from European funds;

- lack of skilled labor;

- availability of poor-quality building materials on the market;

- insufficient control over compliance with building codes;

- short construction guarantee period - 2 years;

- almost complete absence of vocational and technical educational institutions, where they train specialists in construction.

Also during the research it is determined that the concept of eco-labeling for the Latvian construction industry is an unknown component.

2. The study examined the materials of the two most important eco-labeling systems in Scandinavia - SWAN and BASTA. The main indicators and criteria for the ecolabeling of buildings in Scandinavia are defined, as well as the results that affect the quality of construction and environmental protection. In the course of the meeting there are meetings with representatives of Swedish companies that offer their customers the entire list of products that conforms to SWAN and BASTA standards. For the German company VWS Befestigungstechnik GmbH, all declarations for goods that are part of the thermal insulation system of SWAN and BASTA buildings have been prepared.

3. The author of the work is a member of the Chamber of Commerce and Industry of Latvia. At the meeting of the building committee of this Chamber, the author raised the issue of eco-labeling in Latvia for discussion. As a result of the discussion, it is concluded that this innovation is promising for Latvia and possibly for future implementation. In Latvia it is necessary to introduce experience on eco-labeling of residential buildings, educational and preschool premises, as well as old people's homes. For this, it is necessary to develop state requirements for building materials, carbon dioxide emissions, waste sorting, noise, light, humidity and ventilation quality. The use of eco-labeling criteria will lead to the use of high-quality building materials at sites, a responsible approach to construction from design to commissioning. In turn, finding people in residential or educational institutions that are carried out on strict criteria will reduce the number of respiratory diseases and allergies.

In the course of the study, the idea of introducing eco-labeling had its opponents - producers and dealers of building materials. In the case of introduction of ecolabeling, the requirements to the quality and composition of building materials will increase. This, on the one hand, will increase competition, on the other hand, will increase the cost of building materials.

In the course of surveys of ordinary buyers who bought building materials for the construction of a private house, one of the important criteria in the opinion of buyers was the indicator of environmental friendliness and safety.

Thus, the introduction of eco-labeling of buildings and building materials is a necessary and feasible project for the construction industry in Latvia. It is necessary to give this issue and research the most serious attention at the state level.

\section{Acknowledgements}

I want to express my gratitude for acquaintance with materials on eco-labeling of buildings in Scandinavia and study of requirements and criteria:

- Mats Sundlo, Purchasing Manager, STO Scandinavia AB (Linkoping, Sweden);

- Lars-Ole Torstensson, Finja AB engineer (Hesleholm, Sweden);

- Markus Bartelmuss, Export Manager of VWS Befestigungstechnik GmbH (Lichtenstein, Germany).

\section{References}

1. BU030c. Construction output at current prices, thsd euro URL: https://data1.csb.gov.lv/pxweb/lv/rupnbuvn/rupnbuvn buvn_isterm/BU030c.px

2. Sauka A., Putninšs T. Ēnu ekonomikas indekss Baltijas valstīs 2009-2017. gadā. URL: http://www.sseriga.edu/en/news-andevents/news/neskatoties-uz-stabilo-ekonomikas-izaugsmi-nuekonomika-latvij-ir-pieaugusi-par-1-3.html

3. Būvkomersantu klasifikācija. Latvijas Būvuzn̄ēmēju Partnerība URL: http://www.latvijasbuvnieki.lv/position/buvkomersantuklasifikacija/ 
4. Būvuzṇēmumi aizvien aicināti atbalstīt būvniecības generālvienošanos; parakstījuši jau 99 \% no kvoruma. Latvijas Būvuznēmēju Partnerība. URL: http://www.latvijasbuvnieki.lv/buvuznemumiaizvien-aicinati-atbalstit-buvniecibas-generalvienosanos/

5. Partnerība, FM un VID paraksta sadarbības memorandu. Latvijas Būvuzn̄ēmēju Partnerība. URL: http://www.latvijasbuvnieki.lv/ 1632-2/

6. FICIL public discussion: «BUILDING TRUST». URL: https:// www.ficil.lv/events/ficil-public-discussion-building-trust/

7. Elektroniskā darba laika uzskaite - pagrieziena punkts Latvijas būvniecībā. URL: http://latvijas-buvnieku-asociacija.lv/?p=2545

8. Revenue of building construction in Latvia from 2009 to 2020 (in million U.S. dollars). URL: https://www.statista.com/ forecasts/393590/latvia-building-construction-revenue-forecastnace-f 4120

9. The Lead market initiative and sustainable construction. Screening national building regulations. Latvia. 14.02.2011. Official website of EU.

10. Increased exchange in the Building Sector. Nordic Council of Ministers, Copenhagen, 2007. 539 p. URL: https://books. google.lv/books?id=YlkFD0f55eIC\&printsec $=$ frontcover $\& \mathrm{hl}=\mathrm{r}$ $\mathrm{u} \# \mathrm{v}=$ onepage \& $\mathrm{q} \& \mathrm{f}=$ false

11. Construction Sector Profile - Estonie, Latvia, Lithuania. Enterprise URL: https://www.enterprisecanadanetwork.ca/ uploads/resources/Construction-Sector-Profile-Estonie-Latvia-Lithuania.pdf
12. Lielgaidina L., Geipele I. Theoretical Aspects of Competitiveness in Construction Enterprises // Business, Management and Education. 2011. Vol. 9, Issue 1. P. 67-80. doi: https:// doi.org/10.3846/bme.2011.05

13. The EU Ecolabel scheme and its application to construction and building materials / Baldo G. L. et. al. // Eco-efficient Construction and Building Materials. 2014. P. 98-124. doi: https://doi.org/10.1533/9780857097729.1.98

14. In 2017, construction output grew by $19.5 \%$. Central Statistical Bureau of Latvia. URL: https://www.csb.gov.lv/en/statistics/ statistics-by-theme/construction-industry-trade/construction/ search-in-theme/2367-construction-and-building

15. Guidance on CLP. European Chemical Agency. URL: https:// echa.europa.eu/web/guest/guidance-documents/guidance-on-clp

16. About BASTA. Guidance to Sustainable Construction Materials. URL: https://www.bastaonline.se/about-basta/aboutbasta/?lang=en

17. What are Ecolabelled products? URL: http://www.svanen.se/ en/About-us/Why-Ecolabelling/

Lisa Inara, Doctoral Student, Baltic International Academy, Riga, Latvia, e-mail: inara.lisa@gmail.com, ORCID: http://orcid.org/ 0000-0003-3087-1846 